\title{
Expression of Anti-Apoptotic Protein Survivin And Tumor Suppressor p53 Protein in Patients with Pulmonary Carcinoma
}

\author{
E. Halasová1, M. Adamkov², E. Kavcová ${ }^{3}$, T. Matáková4, L. Musák ${ }^{1}$, D. Vybohová ${ }^{5}$, M. Janícková ${ }^{6}$, \\ D. Mistuna ${ }^{7}$, A. Singliar ${ }^{8}$ \\ ${ }^{1}$ Institute of Medical Biology, ${ }^{2}$ Institute of Histology and Embryology, ${ }^{3}$ Clinics of Pneumophthisiology, \\ ${ }^{4}$ Institute of Medical Biochemistry, and ${ }^{5}$ Institute of Anatomy, Jessenius Faculty of Medicine, Comenius University Martin, Slovakia; \\ ${ }^{6}$ Clinics of Stomatology and Maxillofacial Surgery and ${ }^{7}$ Clinics of Surgery, Jessenius Faculty of Medicine, Comenius University, Martin and \\ Faculty Hospital in Martin, Slovakia; ${ }^{8}$ Department of Pathology, Hospital in Dolny Kubín, Slovakia
}

\begin{abstract}
Background: Survivin is one of the inhibitors of the apoptosis gene family that has been implicated in both inhibition of apoptosis and mitosis regulation. p53 is one of the tumor suppressor genes; prevents tumor formation through cell cycle blocking and eliminates damaged cells via activation of apoptosis.

Objective: To investigate the possible regulation of survivin by $\mathrm{p} 53$, we examined the expression of both proteins in 67 patients with diagnosed lung cancer using immunohistochemical visualization.

Results: Survivin was predominantly expressed in both nucleus and cytoplasm, whereas p53 was expressed in the nucleus. There was a negative correlation between survivin and p53 expression. A decreased intensity of expression and fewer cells positive for survivin in small cell lung cancer in comparison with other lung cancer types were detected. There was no significant difference in the intensity of expression and the number of cells positive for p53 between small cell and non-small cell lung cancer types.

Conclusion: The present study suggests that survivin expression, as opposed to that of $\mathrm{p} 53$, is decreased in small cell lung cancer, which may differentiate this cancer from other lung cancer types other types.
\end{abstract}

Key words: immunohistochemistry, lung cancer, p53, survivin

\section{INTRODUCTION}

Apoptosis or programed cell death is needed for the maintenance of cell homeostasis and to destroy cells that represent a threat to the integrity of an organism. Apoptosis can be induced by either specific extracellular signals or internal stimuli. The molecular mechanisms involved in apoptotic enzymatic pathway have been sufficiently reviewed [1]. The protein p53 plays an important role in apoptosis induction. It acts as a transcription factor which is in humans encoded by the TP53 gene $[2,3]$. p53 is activated by various stress signals as radiation (UV, gamma, or X-ray), carcino- gens (polycyclic aromatic carbohydrates, heavy metals), oxidative stress, hypoxia, oncogene activation, telomere, and others [4]. Apoptosis induction is one of the main functions of $\mathrm{p} 53$. Many genes are involved in p53 dependent apoptotic pathways. Based on the pathways involved, the pro-apoptotic genes can be classified into three main groups:

1. Genes for 'death receptor family'. p53 can induce apoptosis through activation of death receptors, such as Apo-1, DR4 and DR5;

2. Genes involved in internal apoptotic pathway. This pathway is activated by stress factors and mediated by mitochondrion. Proteins of Bcl-2 family play the main function in this pathway. In p53-mediated apoptosis BAX, PUMA, and Noxa proteins are involved. Bcl-2 is an anti-apoptotic protein inhibited by $\mathrm{p} 53$;

3. Other target genes. Many other members of the apoptotic machinery can be activated though p53 in apoptosis inducted by DNA damage, such as Apaf1 or caspase 6 [5-8].

The expression and activity of p53 is precisely regulated at many levels [9]. p53 prevents tumor formation through cell cycle blocking and eliminates damaged cells. Mutations or inactivation of p53 are the most frequent changes in human tumorous cells [10]. On the other hand, survivin is an inhibitor of the apoptosis (IAP) gene family, which has been implicated in both inhibition of apoptosis and mitosis regulation [11]. Survivin upregulates genes in tumor tissues [12]. High survivin expression is related to poor prognosis in many cancer types $[13,14]$ Some investigations have shown that p53 leads to the repression of survivin in non-small lung cancers [15]. There are many studies pointing to the expression of the proteins mentioned in non-small cell lung cancers, but only few in small cell carcinomas [16-18]. Therefore, in the present study, we examined the expression and correlation of p53 and survivin in different lung cancer cells. 


\section{Material And Methods}

An institutional Ethics Committee approved the protocol of this study. One hundred samples obtained from operated pulmonary carcinoma patients were evaluated for survivin and p53 expression. Sixty seven of them were enrolled into the study. The remaining cases had to be excluded because of specimens' damage. Hematoxylin and eosin stained slides from each case were independently reviewed by two pathologists to ascertain the diagnosis based on morphological and immunohistochemical parameters and were correlated with clinical data. Three sections, $4 \mu \mathrm{m}$ thick, obtained from each paraffin block, were stained for p53 and survivin proteins. To achieve greater adherence of sections to glass surface, silanized slides (DAKO, Denmark) were used, kept in an oven for $2 \mathrm{~h}$ at $56^{\circ} \mathrm{C}$. Then, the sections were deparaffinized in xylene for $20 \mathrm{~min}$, rehydrated in a series of descending ethanol concentrations, and washed with phosphate-buffered saline (PBS). Endogenous peroxidase activity was blocked with $3 \% \mathrm{H}_{2} \mathrm{O}_{2}$ for $30 \mathrm{~min}$. Antigen unmasking was achieved by heating the sections, immersed in a target solution (DAKO), in a hot water bath $\left(96^{\circ} \mathrm{C}\right)$ for $45 \mathrm{~min}$. Immunohistochemical staining was performed using monoclonal mouse anti-p53 antibody (DAKO, Clone DO-7, dilution 1:50) and monoclonal mouse anti-survivin antibody (DAKO, Clone12C4, dilution 1:50). After overnight incubation, the p53 and survivin antigens were visualized with an LSAB Visualization System (DAKO) using 3,3'-diaminobenzidine chromogen as a substrate, according to manufacturer's instructions. All sections were counterstained with Mayer's hematoxylin (DAKO). Negative controls were obtained by simple omitting the primary antibodies.

\section{Evaluation of ImMUNOHISTOCHEMICAL STAINING}

Survivin and p53 antibody stained sections were examined under light microscopy and the positivity of their expression was determined semi-quantitatively. In each case, the following features were assessed: (i) intensity of staining scored as absent $(0)$, weak $(+)$, moderate
$(++)$, and strong $(+++)$; (ii) relative number of positively stained cells: more or less than $25 \%(\geq 25$ or $\leq 25 \%$ per field of view; and (iii) subcellular localization of p53 and survivin antigens: nuclear (N), cytoplasmic (C), or both (NC).

\section{STATISTICAL ANALYSIS}

Chi-square $\left(\chi^{2}\right)$ test or Fischer's exact test was used for the statistical analysis to compare the observed parameters between survivin and p53 immunoreactivity. Spearman's coefficient was used to estimate the correlation between parameters. All statistical calculations were performed using Microsoft Excel and MedCalc v.5 software for Windows.

\section{RESULTS}

The results of the expression profiling are summarized in Table 1 and illustrated in Fig. 1 (Panels A and B). Survivin was predominantly expressed in both nucleus and cytoplasm in 58 (97\%) of cases (Fig. 1A), whereas p53 was in the nucleus alone in $56(89 \%)$ of cases (Fig. 1B). A majority of cases $(61 ; 92 \%)$ showed $\geq 25 \%$ of positively stained cells for p53 compared with just 18 cases $(29 \%)$ with $\geq 25 \%$ of positively stained cells per field of view for surviving; the difference was significant $\left.-\chi^{2}=53.8 ; \mathrm{P}<0.001\right)$. There was

Table 1. Expression of survivin and p53 in 67 biopsies from patients with lung cancer.

\begin{tabular}{l|llll|ll|lll}
\hline & \multicolumn{4}{|c|}{ I } & \multicolumn{2}{c|}{$\%$} & \multicolumn{3}{c}{ SL } \\
\hline & 0 & + & ++ & ++ & $<25$ & $>25$ & $\mathrm{~N}$ & $\mathrm{C}$ & $\mathrm{NC}$ \\
Survivin & 7 & 20 & 32 & 8 & 43 & 18 & 1 & 1 & 58 \\
p53 & 4 & 13 & 29 & 21 & 5 & 61 & 56 & 1 & 6 \\
\hline
\end{tabular}

I - intensity of immunoreactivity: $(+)$ weak, $(++)$ moderate, $(+++)$ strong; \% - percent of labeled cells;

SL - subcellular localization: N-nuclear, C- cytoplasmic, NCnuclear and cytoplasmic.
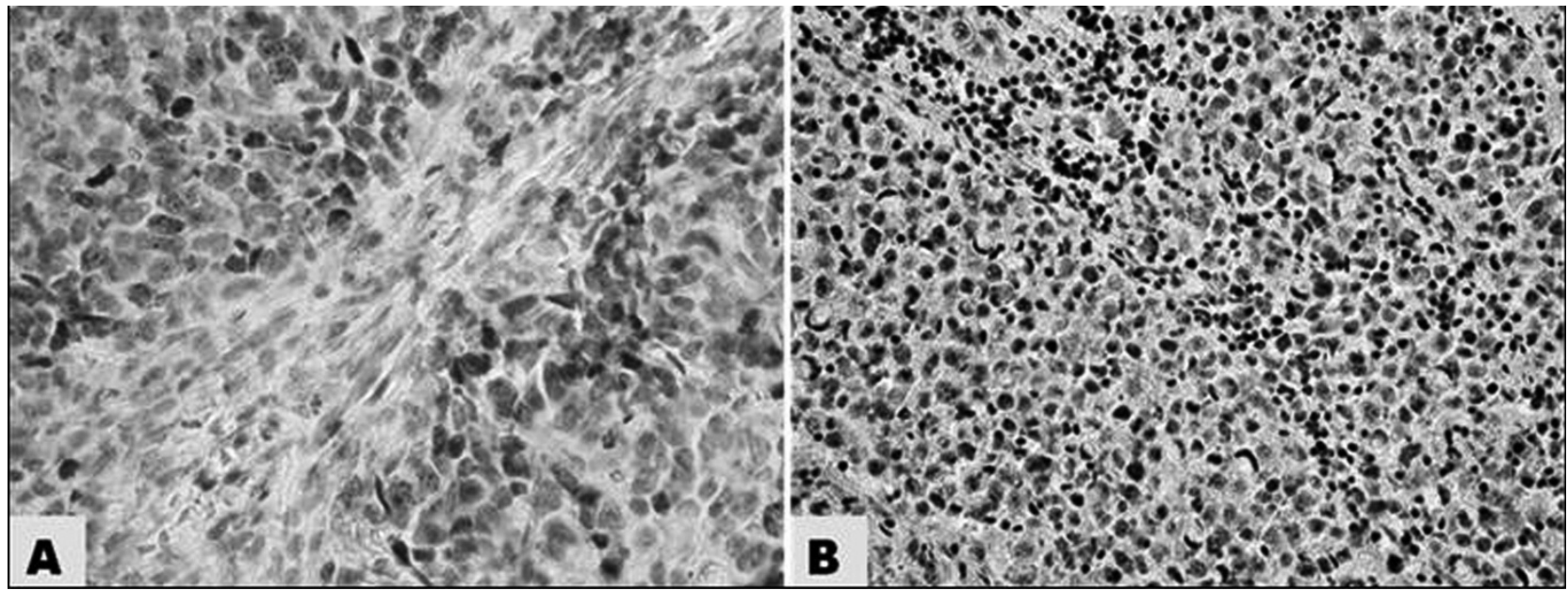

Fig. 1. Panel A - Combined cytoplasmic and nuclear survivin immunopositivity in tumor cells (primary magnification -600x); Panel B - Nuclear p53 immunopositivity in tumor cells (primary magnification - 400x). 
a negative correlation $(\mathrm{r}=-0.72)$ between the survivin and p53 expressions. It seems that p53 down-regulated the expression of survivin. A comparison of nonsmall and small cell lung cancer types for survivin expression showed a significant decrease in the intensity and a fewer number of positive cells in small cell lung cancer $\left(\chi^{2}=15.3 ; \mathrm{P}<0.001\right.$ and $\chi^{2}=8.4 ; \mathrm{P}<0.05$, respectively). In contrast, the expression and the number of cells positive for p53 did not differ significantly between small cell and non-small cell lung cancer types.

\section{Discussion}

p53 is a multifunctional protein that regulates cell division and activates apoptosis. On the other hand, survivin can act as an apoptosis inhibitor, being overexpressed in many malignancies, including lung carcinoma. A lot of studies have been focused on the relationship between survivin and p53 expression, but the results have been quite controversial. Jin et al. [16] suggested that survivin expression is negatively regulated by p53. Nakano et al. [17] investigated survivin and p53 expression in specimens from 140 non-small cell lung cancer patient. They found significant differences in survivin expression in squamose cell carcinomas and adenocarcinomas. Furthermore, survivin expression in tumors with mutant p53 was significantly higher than that in tumors with a wild-type p53. The authors concluded that the survivin gene expression is negatively regulated by p53 in NSCLC, which can inhibit apoptosis and accelerate tumor proliferation to produce more aggressive carcinomas. The findings of the present study are in accord with those results. We found a negative correlation between p53 and survivin expressions, which confirms a relationship between these two opposite proteins. However, opposing results were published by Akjurek et al. [18]. The aim of those authors' immunohistochemical study was to investigate the role of survivin in the early steps of lung carcinogenesis and non-small cell carcinomas, and its relation to the expression of $\mathrm{p} 53$. They found no correlation between survivin and p53 expressions, although the patients in whom survivin was expressed had a significantly worse prognosis.

Molecular mechanisms of tumor progression and apoptosis are still unclear. Several predictors, such as nodal involvement, tumor stage, and surviving and p53 expressions have been reported; however, the relationship between p53 or survivin and the prognosis of lung cancer patients is still controversial [19-21]. The present study calls attention to the expression of survivin in relation to p53 in small cell lung carcinoma, suggesting that survivin expression is decreased in this cancer type compared with other types. Further studies are required to explain and understand these findings.

Acknowledgments: Supported by MZ 2007/48-UK-13 and AV 4/2026/08 Grants.

Conflicts of interest: No conflicts of interest were declared by the authors in relation to this article.

\section{REFERENCES}

[1] Jinz Z, El-Deiry WS. Overview of cell death signaling pathways. Cancer Biol Ther 2005; 4: 139-163.

[2] Matlashewski G, Lamb P, Pim D, Peacock J, Crawford L, Benchimol S. Isolation and characterization of a human p53 cDNA clone: expression of the human p53 gene. EMBO J 1984; 3: 3257-3262.

[3] Isobe M, Emanuel BS, Givol D, Oren M, Croce CM. Localization of gene for human p53 tumor antigen to band 17p13. Nature 1986; 320: 84-85.

[4] Pluquet O, Hainaut P. Genotoxic and non-genotoxic pathways of p53 induction. Cancer Lett 2001; 174: 1-15.

[5] Moll UM, Zaika A. Nuclear and mitochondrial apoptotic pathways of p53. FEBS Lett 2001; 493: 65-69.

[6] Schuler M, Green D. Mechanisms of p53-dependent apoptosis. Biochem Soc Trans 2001; 29: 36-42.

[7] Pietenpol JA, Stewardt ZA. Cell cycle checkpoint signaling: Cell cycle arrest versus apoptosis. Toxicology 2002; 181: 475-481.

[8] Yu J, Zhang L. The transcriptional targets of p53 in apoptosis control. Biochem Biophys Res Commun 2005; 331: 851-858.

[9] Coutts AS, Thangue N. The p53 response during DNA damage: impact of transcriptional cofactors. Biochem Soc Symp 2006; 73: 181-189.

[10] Deng Y, Wu X. Peg3/Pw1 promotes p53-mediated apoptosis by inducing Bax translocation from cytosol to mitochondria. Proc Natl Acad Sci USA 2000; 97: 1205012055.

[11] Altieri DC. Validating survivin as a cancer therapeutic target. Nat Rev Cancer 2003; 3: 46-54.

[12] Velculescu VE, Madden SL, Zhang L, Lash AE, Yu J, Rago C, Lal A, Wang CJ, Beaudry GA, Ciriello KM, Cook BP, Dufault MR, Ferguson AT, Gao Y, He TC, Hermeking $\mathrm{H}$, Hiraldo SK, Hwang PM, Lopez MA, Luderer HF, Mathews B, Petroziello JM, Polyak K, Zawel L, Kinzler $\mathrm{KW}$, et al. Analysis of human transcriptomes. Nat Genet 1999; 32: 387-388.

[13] Kawasaki H, Altieri DC, Lu CD, Toyoda M, Tenjo T, Tanigawa N. Inhibition of apoptosis by survivin predicts shorter survival rates in colorectal cancer. Cancer Res 1998; 58: 179-185.

[14] Yamashita S, Masuda Y, Kurizaki T, Haga Y, Murayama T, Ikei S, Kamei M, Takeno S, Kawahara K. Survivin expression predicts early recurrence in early-stage breast cancer. Anticancer Res 2007; 27: 2803-2808.

[15] Mirza A, McGuirk M, Hockenberry TN et al. Human survivin is negatively regulated by wild-type p53 and participates in p53-dependent apoptotic pathway. Oncogen 2002; 21: 2613-2622.

[16] Jin HO, Yoon SI, Seo SK, Lee HC, Woo SH, Yoo DH, Lee SJ, Choe TB, An S, Kwon TJ, Kim JI, Park MJ, Hong SI, Park IC, Rhee CH. Synergistic induction of apoptosis by sulindac and arsenic trioxide in human lung cancer A549 cells via reactive oxygen species-dependent downregulation of survivin. Biochem Pharmacol 2006; 7210: 1228-1236.

[17] Nakano J, Huang CL, Liu D, Ueno M, Sumitomo S, Yokomise H. Survivin gene expression is negatively regulated by p53 tumor supressor gene in non-small cell lung cancer. Int J Oncol 2005; 27: 1215-1221.

[18] Akyürek N, Memis L, Ekinci O, Köktürk N, Oztürk C. Survivin expression in pre-invasive lesions and non-small cell lung carcinoma. Virchows Arch 2006; 449: 164170.

[19] Mitsudomi T, Hamajima N, Ogawa M, Takahashi T. Prognostic significance of p53 alterations in patients with non-small cell lung cancer: a meta-analysis. Clin Cancer Res 2000; 6: 4055-4063. 
[20] Fan J, Wang L, Jiang GN, He WX, Ding JA. The role of survivin on overall survival of non-small cell lung cancer, a meta-analysis of published literatures. Lung Cancer 2008; 61: 91-96.

[21] Yamashita S, Chujo M, Miyawaki M, Tokuishi K, Anami K, Yamamoto S, Kawahara K. Combination of p53AIP1 and survivin expression is a powerful prognostic marker in non-small cell lung cancer. J Exp Clin Cancer Res 2009; 28: 22.
Corresponding author:

Marian Adamkov

Institute of Histology

Jessenius Faculty of Medicine

Malá Hora 4 St.

03754 Martin

Slovakia

Phone: +421434131531

E-mail: adamkov@jfmed.uniba.sk 